\title{
ELIGIBILITY OF STUDENT WORKSHEET (LKPD) BASED ON 5E LEARNING CYCLE WITH SCIENCE PROCESS SKILLS (SPS) ON ACID- BASE MATERIAL
}

\author{
Aulia Amalia Ahmadiyanti ${ }^{1}$ *, Rusly Hidayah ${ }^{2}$ \\ ${ }^{12}$ Program Studi Pendidikan Kimia, Universitas Negeri Surabaya. Jalan Ketintang \\ Surabaya, Jawa Timur 60231, Indonesia. \\ * Coressponding Author. E-mail: ruslyhidayah@unesa.ac.id
}

Received: 13 Januari 2021

Accepted: $\quad 24$ Mei 2021

Published: 28 Mei 2021

doi: $10.29303 /$ cep.v4i1.2393

This study aims to measure the eligibility of a developed learning media. The media is a student worksheet (LKPD). The LKPD being developed is LKPD with a process of science skills based on the $5 \mathrm{E}$ Learning Cycle in acid-base material. This type of research is descriptive quantitative research using the ADDIE model. Researchers used a validation sheet as a validation instrument. The validation was carried out by three experts in chemistry education. The validation aspects that are assessed are aspects of content, presentation, language, and graphics. Based on the research results, it shows that the validity of the developed LKPD can be criticized as "very valid" in every aspect with a proportion value of $82.67 \%$ in content aspects, $86.67 \%$ in presentation aspects, $87.78 \%$ in language aspects, and $88.33 \%$ in graphic aspects. LKPD which is considered very feasible is expected to be a teaching material that can increase understanding of concepts and science process skills (SPS).

Kata Kunci: LKPD validity, acid base, science process skills, 5E Learning Cycle.

\section{Kelayakan Lembar Kerja Peserta Didik (LKPD) Berbasis Learning Cycle $5 E$ dengan Keterampilan Proses Sains (KPS) pada Materi Asam Basa}

\begin{abstract}
Penelitian ini memiliki tujuan untuk mengukur validitas dari suatu media pembelajaran yang dikembangkan. Media tersebut adalah lembar kerja peserta didik (LKPD). LKPD yang dikembangkan adalah LKPD dengan keterampilan proses sains berbasis Learning Cycle 5E dalam materi asam basa. Jenis penelitian ini yaitu penelitian kuantitatif deskriptif menggunakan model ADDIE. Peneliti menggunakan lembar validasi sebagai instrumen validasi. Validasi dilakukan oleh tiga ahli dalam pendidikan kimia. Aspek validasi yang dinilai adalah aspek isi, aspek penyajian, aspek Bahasa, dan aspek kegrafisan. Berdasarkan hasil penelitian ini menunjukkan bahwa validitas dari LKPD yang dikembangkan dapat dikriteriakan "sangat valid" pada setiap aspek dengan nilai persentase 82,67\% aspek isi, 86,67\% aspek penyajian, 87,78\% aspek Bahasa, dan 88,33\% aspek kegrafisan. LKPD yang dianggap sangat layak diharapkan dapat menjadi bahan ajar yang bisa meningkatkan pemahaman konsep serta keterampilan proses sains (KPS).
\end{abstract}

Keywords: validitas LKPD, asam basa, keterampilan proses sains, learning cycle $5 E$

\section{INTRODUCTION}

Teaching and learning activities are a process of communication from two directions. Two-way communication means communication carried out by teachers and students. Teachers carry out teaching activities, while students carry out learning activities (Syaiful, 2006).

Chemistry is a complex subject. This is because chemistry does not only include the concept of calculation, but also does practical work so that chemistry can be used in life such as 


\section{Chemistry Education Practice, 4 (1), 2021 - 41}

Ahmadiyanti, Hidayah

acid-base matter. This is a training for students to understand nature by making observations to build knowledge and skills (Kemendikbud, 2014).

Learning activities still have some problems at this time such as students' low interest in learning and understanding of the concepts they have is still lacking. This is because the atmosphere of the learning process in the classroom is still passive and unpleasant. Most passive students only become listeners during the learning process (Dimyati \& Mudjiono, 2002). The science learning process emphasizes providing direct experience to students through scientific work steps as done by scientists which is known as the scientific method. In the learning practice, learning activities through a scientific work process will involve a series of skills called science process skills. In the scientific approach the learning process tends to be student-centered so that they are more active in understanding what is learned based on what they find in the field (Mayasari, Syamsurizal, \& Maison, 2015). Based on the 2013 Curriculum, what is to be achieved in learning is that students have scientific thinking skills which include observing, asking questions, processing information, presenting information, and concluding. The teacher should be able to determine an appropriate learning model that is not only able to improve learning outcomes but also improve science process skills. One of the solution is by training science process skills (SPS) in the learning process (Aktamis \& Yenice, 2010).

The problem of science process skills is still an important issue in science education. Ergul (2011) argue that the science process skills are skills of a scientist. Science process skills are described as physical and mental abilities that can make learning more effective (Nwosu \& Okeke, 1995). According to Bilgin (2006) scientific process skills are the understanding of a method and procedure of scientific investigation.

Science process skills according to Gagne (in Purwandono, 2000) are skills that are used by all scientists, and can be used to understand phenomena, the behavior of scientists can be learned and utilized in living life.

Human didn't bring the science process skills (SPS) since we were born, but science process skills are skills that need to be trained. In living everyday life, scientific methods are important for understanding various phenomena in life. Students with process skills make these students act actively during learning because they are required to understand concepts with scientific methods. Science process skills are special skills in the process of simplifying a science learning. This is what makes learning run well because students are able to do active learning (Carey, 1989).

According to Dahar (1996), science process skills are students' skills in applying scientific methods in understanding, elaborating and increasing knowledge. Science process skills make students less passive. This is because they are given the opportunity to work with science. So that students do not just listen to the teacher explain a material.

Trianto (2010) states that science process skills are expertise in directing students to understand elaborating concepts. According to Harlen (1999), students who have process skills will be scientists who have scientific literacy and the ability to use scientific information in carrying out in daily life.

The teaching and learning process of chemistry emphasizes the science process skills approach so the importance of developing LKPD based on science process skills. This development will allow students to find facts, build concepts, theories, scientific attitudes and can have a positive effect on the quality of the educational process and educational products (Hartono \& Ibrahim, 2014).

The process skills tested in this study were taken from Nur (2011) namely problem formulation, hypothesis preparation, designing experiments, determining variables, collecting data, analyzing data, and concluding. If SPS is trained, it will get the result of an increase in the pre test and post test in Rusly and Lailiy's research (2018).

According to Slavin (1995), students are considered easy to understand the concept by conducting peer tutoring or having discussions with their own friends. The cycle learning model is a model of student-centered teaching and learning activities (Shoimin, 2014). Learning cycle $5 \mathrm{e}$ is a learning model that can improve students' science process skills. The 5E learning cycle model is a constructivism learning model that is popular compared to other learning cycle models (Hanuscin \& Lee, 2007). Learning cycle $5 \mathrm{E}$ uses the principle of constructivism which means that students play an active role in developing understanding of the material being discussed in a lesson. Constructivist theory in the learning process makes students have to be able to build their knowledge through involvement in 


\section{Chemistry Education Practice, 4 (1), 2021 - 42}

Ahmadiyanti, Hidayah

the learning process. So that teaching and learning activities will be more student-centered (Soebagio, 2000).

In supporting the learning process, a learning media is needed. To obtain an interesting learning process, educators must have methods, models, media and approaches that are appropriate to the circumstances and conditions of students who are going to learn so that learning objectives can be achieved. One of the components to achieve learning objectives is to use teaching materials. Teaching materials can be in the form of printed teaching materials, visual teaching materials, audio visual teaching materials, multimedia teaching materials, and real objects. The importance of using teaching materials in learning, namely as a guide for students on the competencies that must be mastered. Teaching materials can help in understanding concepts that cannot be explained verbally. Student Worksheet (LKPD) is one of the printed teaching materials in the form of paper sheets containing material, summaries, and instructions for implementing learning tasks that must be done by students which refer to the basic competencies that must be achieved (Prastowo A. , 2015). Student worksheets contain activities or steps that must be done by students in finding concepts in the learning process. The content of the LKPD adjusts to the basic competencies that must be achieved (Prastowo A. , 2012).

Experiment-based LKPD is a worksheet that contains practical instructions using tools and materials. Experiment-based LKPD is also inseparable from science process skills which include a scientific process in conducting investigations. By conducting experiments students can find their own concepts to be studied, because students do their own experiments that require problem solving.

LKPD that uses the 5E learning cycle model with science process skills can help learning acid-base material because acid-base material is very suitable to use the practicum method. The practicum method can be used to train science process skills in students so that it can make it easier to understand the material. The $5 \mathrm{E}$ Learning cycle model has stages that match science process skills. Some acid-base practicums include testing acid-base properties, measuring acid-base $\mathrm{pH}$, and utilizing natural ingredients as natural indicators of acid-base. So it is hoped that with the help of this LKPD, students can more easily understand the material and students can improve their science process skills in themselves.

In improving the process skills of students, the researcher will develop a stundents' worksheet (LKPD) based on the 5E learning cycle model with science process skills on acidbase material. This is the basis of research conducted by researchers whose aim is to assess the validity of the developed LKPD in terms of several aspects, those are aspects of content, presentation, language, and graphics. LKPD that are deemed appropriate are expected to be teaching materials that can improve understanding of concepts and science process skills (SPS).

\section{METHODS}

The type of the research is the development of the ADDIE model. The ADDIE Development Research Model, as the name implies, is a model that involves the stages of model development with five steps / development phases including: Analysis, Design, Development or Production, Implementation or Delivery and Evaluations).

The analysis stage comes from student analysis and material analysis. At the design stage, it consists of designing the preparation of

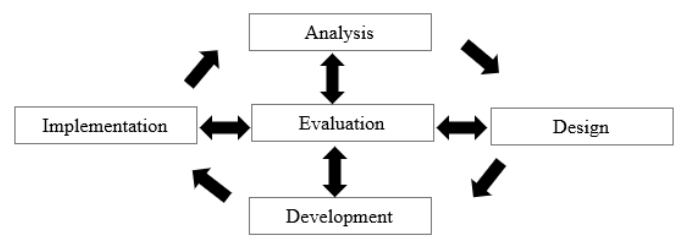

Figure 1. Addie Model

materials and tasks and designing supporting images and presentation of LKPD. The development stage consists of a validity test conducted by experts. The implementation stage consist of training implementaion and observation. The Evaluation stage consist of results.

This study presents the quality of the developed LKPD. In assessing the feasibility of LKPD, researchers use the validation sheet filled out by three experts of chemical education. The aspects of validity that are measured include aspects of content, presentation, language, and graphics. The data from the LKPD assessment were analyzed using descriptive quantitative methods by giving an overview and describing the research on the LKPD with a percentage of 
the value obtained. The percentage of this validation assessment is obtained from the following Likert scale calculation.

Table 1. Likert Scale

\begin{tabular}{cc}
\hline Points of Scale & Score \\
\hline Very bad & 1 \\
Bad & 2 \\
Moderate & 3 \\
Good & 4 \\
Very good & 5 \\
\hline
\end{tabular}

The validity score obtained is calculated using the following eligibility percentage formula (Sugiyono, 2011):

$$
P=\frac{\sum \text { Score obtained }}{\sum \text { Criterion score }} \times 100 \%
$$

Information:

$\mathrm{P}=$ Validity percentage

The figure obtained is modified using the conversion of the validity attainment level as follows:

Table 2. Percentage of Feasibility Analysis

\begin{tabular}{cc}
\hline Percentage (\%) & Category \\
\hline $0-20$ & Very invalid \\
$21-40$ & Invalid \\
$41-60$ & Quite valid \\
$61-80$ & Valid \\
$81-100$ & Very valid \\
\hline
\end{tabular}

(Riduwan, 2015)

Ghozali (2009) states that reliability is a tool for measuring a questionnaire which is an indicator of variables or constructs. A questionnaire is said to be reliable if a person's answer to a statement is consistent or stable over time. The reliability of a test refers to the degree of stability, consistency, predictive power, and accuracy. Measurements that have high reliability are measurements that can produce reliable data. Testing the reliability of the instrument in this study was assisted by the SPSS 26 application using the Alpha formula calculation. The level of reliability is empirically indicated by a number called the reliability coefficient value. High reliability is indicated by the value of rxx close to number 1. General agreement is that the reliability is considered satisfactory if $\geq 0.700$.

\section{RESULTS AND DISCUSSION}

The learning media developed in this study were LKPD based on learning cycle 5E with science process skills (SPS). There are three LKPDs developed by researchers. The first LKPD is about testing the acid-base properties of materials in the surrounding environment using litmus paper. The second LKPD is about determining the $\mathrm{pH}$ of several solutions based on the $\mathrm{pH}$ trajectory of several acid-base indicators. Meanwhile, the last LKPD is about testing the acid-base properties of a solution from materials that are easy to find in the surrounding environment by using natural ingredients as acidbase indicators. All LKPDs are developed using problems in daily life which are expected to be able to motivate students to apply concepts in daily life. In the LKPD some scientific process skills are developed which are listed in the contents of the LKPD.

In this study using the ADDIE model development design with the following steps:

a. Analysis

Analyzing material that is difficult for students to understand, activities that students like during the learning process, obstacles experienced by students during the learning process. From the results of the student questionnaire analysis, the majority of students stated that acid-base is a material that is difficult to understand, students also prefer to do learning activities using the practicum method according to them the practicum method can make it easier to understand the material, students also like to do group learning, as for the obstacles they experience. by students in studying acid-base material is the lack of practicum and the material they learn is considered difficult.

b. Design

At this stage, LKPD designs begin, including designing the cover and the contents with an attractive appearance, providing illustrations to students so that it is easy to understand the material, adjusting the content of science process skills with the 5E learning cycle model syntax.

c. Development

Realizing the LKPD design made by making lesson plans, media, and acid-base learning materials.

d. Implementation

In this stage, the design and methods that have been developed are packaged in LKPD and then implemented in students with the aim of 
guiding students according to the $5 \mathrm{E}$ learning cycle model with science process skills.

e. Evaluation

Evaluation of the pretest and posttest was carried out so that it could be seen the effect of LKPD on student learning outcomes.

The results of the needs analysis showed that there were many student worksheets that did not use science process skills, so it was decided to develop LKPD based on science process skills which were expected to be able to help improve students' science process skills.

At the design stage, the materials needed to design student worksheets based on science process skills are materials, pictures that support acid-base material, the results of acid-base practicum using natural materials that are easily found in daily life.
This LKPD has been tested for reliability using SPSS 26 by using Alpha calculations resulting in an Alpha value of 0.882 which means that this LKPD is reliable. Alpha value $>0.7$ means sufficient reliability, while alpha $>0.80$ suggests that all items are reliable and all tests consistently have strong reliability.

The LKPD that was made was assessed by three chemical education experts with five aspects being assessed including aspects of content, presentation, language, and graphics. LKPD is said to be feasible as a learning medium if each component gets a percentage of $\geq 61 \%$ (Riduwan, 2015). However, LKPD needs to be revised according to the validator's assessment. The following is the result of the validator's assessment of the developed LKPD:

Table 3. LKPD Eligibility Assessment Results

\begin{tabular}{|c|c|c|c|c|c|}
\hline \multirow[b]{2}{*}{ No. } & \multirow[b]{2}{*}{ Aspect } & \multirow[b]{2}{*}{ Validator } & \multicolumn{2}{|c|}{ Percentage analysis (\%) } & \multirow[b]{2}{*}{ Category } \\
\hline & & & $\overline{\sum P}$ & $\bar{P}$ & \\
\hline \multirow[t]{3}{*}{1} & Content & 1 & $80 \%$ & & \\
\hline & & 2 & $80 \%$ & $82,667 \%$ & Very valid \\
\hline & & 3 & $88 \%$ & & \\
\hline \multirow[t]{3}{*}{2} & Presentation & 1 & $89,09 \%$ & & \\
\hline & & 2 & $83,64 \%$ & $86,67 \%$ & Very valid \\
\hline & & 3 & 87,27 & & \\
\hline \multirow[t]{3}{*}{3} & Language & 1 & $83,33 \%$ & & \\
\hline & & 2 & $80 \%$ & $87,78 \%$ & Very valid \\
\hline & & 3 & $100 \%$ & & \\
\hline \multirow[t]{4}{*}{4} & Graphics & 1 & $85 \%$ & & \\
\hline & & 2 & $80 \%$ & $88,33 \%$ & Very valid \\
\hline & & 3 & $100 \%$ & & \\
\hline & \multicolumn{2}{|c|}{ Total } & & $86,36 \%$ & Very valid \\
\hline
\end{tabular}

Based on the results of the feasibility assessment of the chemical education experts, all aspects that are considered to be categorized as "very valid" means that LKPD is suitable to be used in the learning process with several revisions provided by the validator. The revisions made are regarding the cover and content. Maiyuni (2016) states that there needs to be an adjustment between the learning objectives and the drafted LKPD definition.

In developing LKPD, the results of LKPD are obtained with the appearance and content as follows:

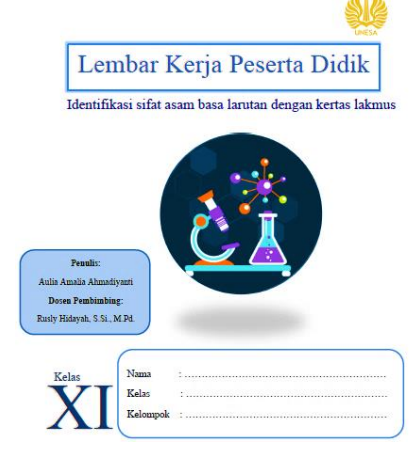

Figure 2. LKPD cover 


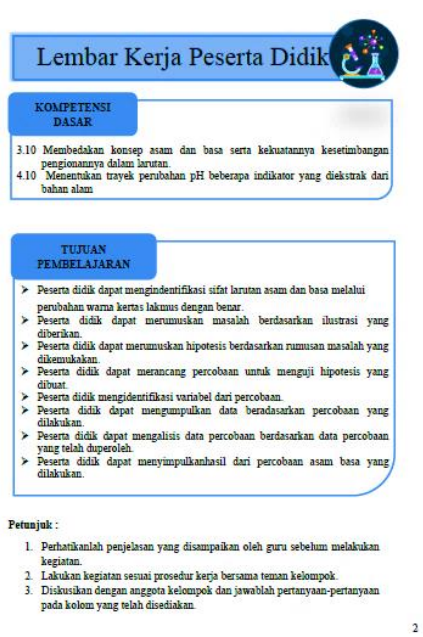

Figure 3. Instructions, Basic Competencies and Learning Objectives in the LKPD

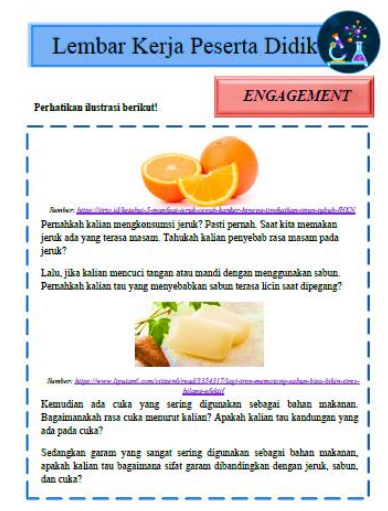

Figure 4. Acid-base Phenomenon in LKPD

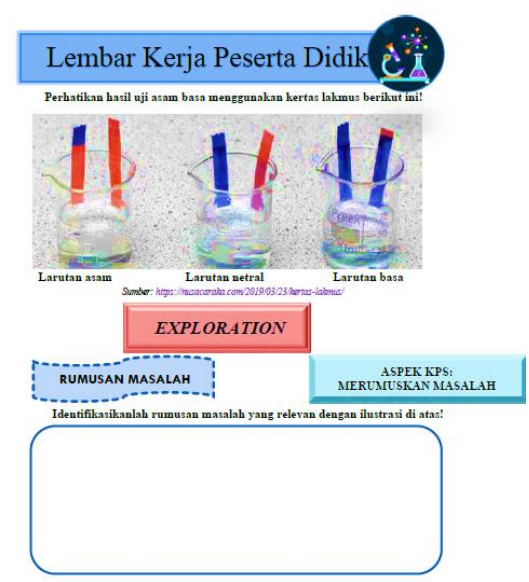

Figure 5. Display of One of the SPS Components in the LKPD

\section{Content Aspect}

The content aspect has a percentage of $82.667 \%$ and is categorized as "very valid". This is because the content of the developed LKPD is in accordance with the KI / KD as well as indicators of competency achievement, accuracy of facts, concepts, illustrations and phenomena presented correctly, the suitability of learning supporting material presented (phenomena) with the development of science and technology, presentation logical and systematic LKPD material based on the sequence of knowledge provided, as well as conformity to the criteria of science process skills, including: formulating problems, making hypotheses, designing experiments, identifying variables, analyzing data and making conclusions. Even though the content aspect is included in the criteria of "very valid", there are still revisions. The revision of the content aspect includes the materials / substances used for practicum which are asked to replace the materials / substances that have been used in one of the developed LKPDs. This is because students get new things and don't get bored easily in doing practicum using the LKPD that is used. The following is a graph of the percentage of the LKPD feasibility assessment on the content aspect:

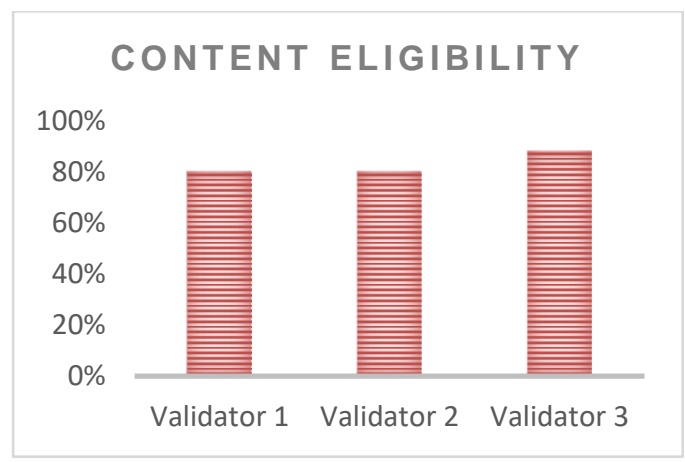

Figure 6. Graph of the percentage of LKPD feasibility assessment on the content aspect

\section{Presentation Aspect}

In the presentation aspect contains the assessment of the clarity of the learning objectives to be achieved, the concepts that are presented in order and balance in each subchapter, the completeness of the information presented in the LKPD, the presentation of images accompanied by information and references, the suitability of writing bibliography with applicable rules, an interesting presentation of LKPD, the cover represents the content of the LKPD, the illustrations or images presented can help understanding concepts, the presentation of the LKPD generates a sense of curiosity, and the completeness of the components of science 
process skills that are presented, including: formulating problems, making hypotheses, designing experiments, identifying variables, analyzing data and interesting conclusion. Assessment in terms of presentation got a percentage of $86.67 \%$ and entered the "very valid" criteria. Even though it is included in the very valid criteria, there is still a revision, namely a cover revision which includes a title revision so that each LKPD has a different title so that it can be distinguished from the three developed LKPD. The following is a graph of the percentage of the LKPD feasibility assessment on the presentation aspect.

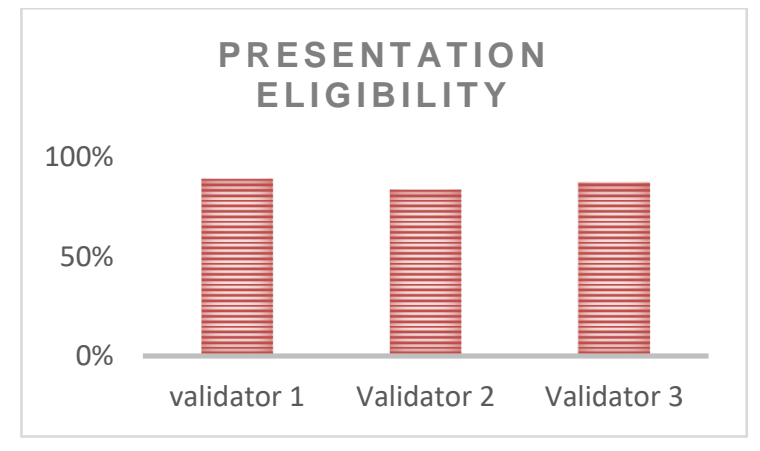

Figure 7. Graph of the percentage of feasibility assessment of LKPD on the presentation aspect

\section{Language Aspect}

In the language aspect, the components that are assessed include the suitability of LKPD writing with students' reading abilities, LKPD writing using terms or symbols or symbols consistently, the suitability of language use in LKPD writing with student development, LKPD writing using Indonesian that is good and correct, writing language or regularity between chapters, subsections, paragraphs and sentences, and writing LKPD using precise and easy to understand terms. According to Wiratno \& Santoso (2011), validity in the aspect of language is a means of communication if it is able to convey the message in text form. The following is a graph of the percentage of the feasibility assessment in terms of language.

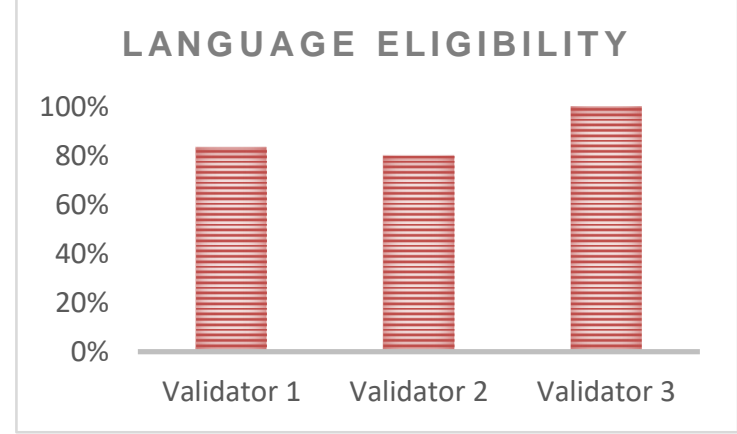

Figure 8. Graph of the percentage of LKPD feasibility assessment on the language aspect

\section{Graphic Aspect}

The graphic aspect contains the assessment of the use of fonts that makes it easier for readers, the suitability of the background with the color of the writing, the harmony of text layout, images and tables, as well as terms, formulas and symbols that are clearly stated. The results of the validator's assessment of the graphic aspects are very valid. It can be concluded that the LKPD developed is in accordance with the needs of the learning process in accordance with Prastowo (2015) who says that in determining the design of LKPD using the appropriate size that can be used according to learning needs. The following is a graph of the percentage of the LKPD feasibility assessment on the graphic aspect.

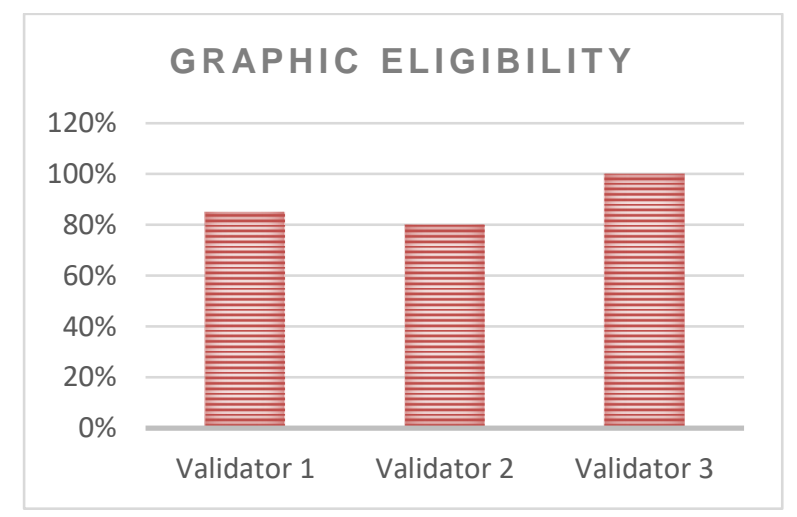

Figure 9. Graph of The Percentage of LKPD feasibility assessment on the graphic aspect

Based on the results of the developed LKPD feasibility assessment, the aspects that received low percentages were the content and presentation aspects. This is due to the content and presentation aspects there are revisions given so that there is still a need for improvement in the developed LKPD. 


\section{CONCLUSION}

Based on the results of the feasibility assessment, it can be concluded that the developed LKPD criteria are "very valid". Validity is assessed from several aspects including aspects of content, presentation, language, and graphics. In these five aspects, each aspect falls into the "very valid" criteria. A developed LKPD which is considered very feasible is expected to be a teaching material that can increase understanding of concepts and science process skills (SPS).

\section{REFERENCES}

Aktamis, H., \& Yenice, N. (2010). Determination of the process skill and critical thinking skill level. Procedia Social and Behavioral Sciences, 2(2), 3282-3288.

Bilgin, I. (2006). The Effects Of Hands-On Activities Incorporating A Cooperative Learning Approach On Eight Grade Students' Science Process Skills And Attitudes Toward Science. Journal of Baltic Science Education, 11(1), 27-37.

Carey, S. E. (1989). An experiment is when you try it and see if it works: a study of grade 7 students understanding of the construction of scientific knowledge. International Journal of Science Education, 11(5), 514-529.

Dahar, R. W. (1996). Teori-Teori Belajar. Jakarta: Erlangga.

Dimyati, \& Mudjiono. (2002). Belajar dan Pembelajaran. Jakarta: Rineka Cipta.

Ergul, R. S. (2011). The Effects of Inquiry-Based Science Teaching on Elementari School Student's Science Process Skills And Science Attitudes. Bulgarian Journal of Science and Education Policy, 5(1), 4868.

Ghozali, I. (2009). Aplikasi Analisis Multivariate dengan Program SPSS . Semarang: UNDIP.
H, R., \& Lailiy, N. (2018). Guided Inquiry Model To Promote Science Process Skill Students on Acid-Base. Advances in Intelligent Systems Research (AISR), 157, 96-97.

Hanuscin, D. L., \& M, H. L. (2007). Using a learning cycle approach to teaching the learning cycle to preservice elementary teachers. Association for Science Teacher Education.

Harlen, W. (1999). Purposes and procedures for assessing science process skill. Assesment in Education: Policy and Practice, 6, 129-145.

Hartono, Z., \& Ibrahim, R. (2014). Pengembangan Buku Panduan Praktikum Kimia Hidrokarbon Berbasis Keterampilan Proses Sains di SMA. Jurnal Pendidikan Kimia, 1(4), 87-93.

Kemendikbud. (2014). Permendikbud No. 59 Tentang Kurikulum 2013 Sekolah Menengah Atas/ Madrasah Aliyah. Jakarta: Kemendikbud.

Maiyuni. (2016). Validitas Lembar Kerja Siswa (LKS) Berbasis Problem Based Learning pada Materi Keanekaragaman Hayati untuk SMA. Jurnal Pelangi, 18(2), 167177.

Mayasari, H., Syamsurizal, \& Maison. (2015). The Development of Students' Worksheets Based on Characters Through Scientific Approach on Statistical Fluid Material for Senior High School. Journal Education Sains, 4(2).

Nur, M. (2011). Modul Keterampilan keterampilan Proses Sains. Surabaya: Universitas Negeri Surabaya Pusat Sains dan Matematika Sekolah (PSMS).

Nwosu, A. A., \& Okeke, E. A. (1995). The Effect of Teacher Sensitization of Students Acquisition of Science Process Skills. 
Journal of Science Teachers' Association of Nigeria (STAN), 30(1), 39-45.

Prastowo, A. (2012). Pengembangan Sumber Belajar. Yogyakarta: PT Pustaka Insan Madani.

Prastowo, A. (2015). Panduan Kreatif Membuat Bahan Ajar Inovatif. Jakarta: Diva Press.

Purwandono, E. (2000). Penerapan Pertanyaan Produktif dalam Mengembangkan Keteramilan Proses Sains Siswa pada Pembelajaran Konsep Pemencaran organisme. Bandung: UPI.

Riduwan. (2015). Skala Pengukuran VariabelVariabel Penelitian. Bandung: ALFABETA.

Shoimin, A. (2014). 68 Model Pembelajaran INOVATIF dalam Kurikulum 2013. Yogyakarta: AR-RUZZ MEDIA.

Slavin, R. E. (1995). Cooperative Learning Theory, Research, and Practice Massachusett. USA: Allymand \& Bacon.

Soebagio, A. (2000). Manajemen Pendidikan Indonesia. Jakarta: Ardadlzya Jaya.

Sugiyono. (2011). Metode Penelitian Pendidikan Pendekatan Kuantitatif, Kualitatif dan $R \& D$. Bandung: ALFABETA.

Syaiful, S. (2006). Konsep dan Makna Pembelajaran. Bandung: ALFABETA.

Trianto. (2010). Model Pembelajaran Terpadu. Jakarta: Bumi Aksara.

Wiratno, T., \& Santoso, R. (2011). Pengantar Linguistik Umum. Jakarta: UT. 